\title{
Development of a low-cost mass culture media for Spirulina platensis
}

\author{
A.C.W.W.M.C.L.K.Coswatte ${ }^{1}$, K.S.P.Munirathna ${ }^{1}$, Chamoda Dissanayake ${ }^{1}$ and S.C.jayamanne ${ }^{1}$ \\ ${ }^{1}$ Department of Animal Science, Faculty of Animal Science and Export Agriculture \\ Uva Wellassa University \\ Badulla, Sri Lanka \\ chamari@uwu.ac.lk
}

DOI: 10.31364/SCIRJ/v9.i03.2021.P0321844

http://dx.doi.org/10.31364/SCIRJ/v9.i03.2021.P0321844

\begin{abstract}
The commercial production of Spirulina sp. has gained worldwide attention due to the fact that they have high nutritional value to be used as a human food supplement. This study aimed to develop a low-cost mass culture media for Spirulina platensis in Sri Lanka for commercial purposes. This study was carried out in three axenic culture media (T1, T2 and T3) by substituting selected fertilizers and costeffective alternative chemicals in the Zarrouk's medium. Five concentration series with three replicates in each medium was inoculated with isolated pure culture of spirulina and commercially available Zarrouk media was taken as the control. The algae were grown under illumination (4000 lux CFL and tungsten filament bulb) and temperature was maintained at $35^{\circ} \mathrm{C}$ inside the culture unit. The growth was measured once in three days for 24 days by counting the number of cells under Euromax light microscope $(\times 4)$ which then was converted as a ratio (Ratio=initial count / present count of the day). Normally distributed growth data were analyzed by one-way ANOVA. According to the results (T1:413.24 $\pm 100.06, T 2: 181.2 \pm 6.64, T 3: 520.8 .24 \pm 24.70$ and Control: 287.16 \pm 7.19 ) $\mathrm{T3}$ medium was identified as the most favorable medium for the growth of Spirulina platensis followed by T1, T2 and Control. The results indicated that formulated $\mathrm{T} 3$ medium for large-scale mass production of protein-rich Spirulina sp. is three times profitable and yields high growth rate than Zarrouk's medium (SM).
\end{abstract}

Key words: Spirulina platensis, Zarrouk medium, growth.

\section{INTRODUCTION.}

Algae are an abundant diverse group of photosynthetic organisms. They inhabit in different aquatic environments since they can tolerate wide range of temperatures, salinities, $\mathrm{pH}$ values and different light intensities. Algae are broadly classified as Chlorophyte (green algae), Rhodophyta (red Algae) and Phaeophyta (brown algae) on the basis of photosynthetic pigments they possess. Classifying algae by size, they range from multicellular macro algae to unicellular microalgae.
Macro algae (seaweed) are multicellular algae visible to the naked eye, while microalgae are microscopic single cells and may be prokaryotic, similar to cyanobacteria, or eukaryotic, similar to Chlorophyta (Khan et al., 2018).

Microalgae as a rich source of nutrients has received worldwide attention to be utilized in industries like food, health, pharmaceuticals and cosmetics. They possess a promising source of proteins, polysaccharides, fatty acids, steroids, carotenoids, vitamins, minerals, bioactive compounds and antioxidants. Growth enhancement techniques and genetic engineering can be used to improve their potential as a future source of renewable bio products (Khan et al., 2018).

One of greatest problem in the world today is global food protein scarcity since protein is an essential part of the diet. Hence, there is an important requirement to find another protein source. At the present status, Spirulina sp. is cultivated worldwide due to fact that Spirulina sp., a single cell protein (SCP) is a new source of protein that can be used in human food and health supplements.

Spirulina sp. is a filamentous, photosynthetic blue green microalga which contains a high content of protein (55-65\%) and all the essential amino acids (Devi M. A., et al., 1984) along with minerals, vitamins (B12), antioxidant pigments (carotenoids) and polysaccharides (Beley et al., 1993; Vonshak, 1997) and have powerful antioxidant and antiinflammatory properties (Liu et al., 2016). Phycocyanin is the main active compound in Spirulina. This Spirulina cell membrane does not contain cellulose, therefore it is easily digestible and absorbed in the human body. The species Spirulina maxima and Spirulina platensis were classified in the genus Spirulina. This study specifically refers one micro algae known as Spirulina platensis. 
Spirulina platensis is the most common and widely distributed micro algae that shows higher growth performances under high temperatures with strong sunshine and highly alkaline conditions (FAO, 2008). It has a short life cycle which helps to duplicate its biomass within 3-5 days (Gohl, 1991). Recently Spirulina platensis were popular in health and food industry as a protein and vitamin supplement to aquatic diets as well as to human beings.

In the process of cultivation, a number of algae production technologies are currently under development. There is no one single way to culture algae at commercial scale. Spirulina sp. is cultured in clean fresh waters under controlled conditions to be used for human nutrition. But in these controlled conditions and media that is formulated using analytical grade chemicals are highly expensive. Hence this study aims to develop a low-cost mass culture media for Spirulina platensis in Sri Lankan context.

\section{METHODOLOGY.}

A. Preparation of pure culture

A dominant culture of Spirulina platensis was prepared using a syringe by suction method to get a pure culture with less algal contaminants. As a first step, needle of syringe was modified with a $30^{\circ}$ of curve. Using this syringe, single cell of spirulina was sucked and culture it in culture plate with 24 wells. Each well contained with $1.5 \mathrm{ml}$ of Zarrouk medium was left for few days to obtain a pure culture of Spirulina sp. All the autoclaved glassware was used in the experiment.

Culture tubes were numbered from one to ten and 9 $\mathrm{ml}$ of Zarrouk medium was added to each culture tube and $1 \mathrm{ml}$ of pure Spirulina platensis inoculum was added to number one culture tube using micro pipette. Then another $1 \mathrm{ml}$ of inoculum was taken from the number one culture tube and added to number two culture tube in the laminar flow. Aeration and light were supplied to the culture tubes to maintain photoperiod, temperature oxygen and agitation in algae culture unit.

\section{B. Formulation of mass culture media}

Three media were formulated as $\mathrm{T} 1, \mathrm{~T} 2$, and $\mathrm{T} 3$ taking Zarrouk medium as the control (TABLE I, II and III). Each medium was consisted with five concentrations (with three replicates) by changing the amount of Nitrogen sources and the composition of each medium. The $\mathrm{pH}$ was maintained 9.5 in each concentration and salinity was maintained at $15 \mathrm{ppt}$.

TABLE I: COMPOSITION OF TREATMENT ONE MEDIUM

\begin{tabular}{|l|c|c|c|c|c|}
\hline \multicolumn{1}{|l|}{ T1 medium } & T1-1 & T1-2 & T1-3 & T1-4 & T1-5 \\
\hline Composition & $16.8 \mathrm{~g}$ & $16.8 \mathrm{~g}$ & $16.8 \mathrm{~g}$ & $16.8 \mathrm{~g}$ & $16.8 \mathrm{~g}$ \\
\hline $\begin{array}{l}\text { Commercial } \\
\text { Grade NaHCO }\end{array}$ & $2.0 \mathrm{~g}$ & $2.0 \mathrm{~g}$ & $2.0 \mathrm{~g}$ & $2.0 \mathrm{~g}$ & $2.0 \mathrm{~g}$ \\
\hline $\mathrm{NaCl}$ & $2.0 \mathrm{~g}$ & $2.5 \mathrm{~g}$ & $3.0 \mathrm{~g}$ & $3.5 \mathrm{~g}$ & $4.0 \mathrm{~g}$ \\
\hline $\begin{array}{l}\text { Urea (Nitrogen } \\
\text { source) }\end{array}$ & $1.0 \mathrm{~g}$ & $1.0 \mathrm{~g}$ & $1.0 \mathrm{~g}$ & $1.0 \mathrm{~g}$ & $1.0 \mathrm{~g}$ \\
\hline Albert Solution & & & & & \\
\hline
\end{tabular}

TABLE II: COMPOSITION OF TREATMENT TWO MEDIUM

\begin{tabular}{|c|c|c|c|c|c|}
\hline \multicolumn{6}{|l|}{ T2 medium } \\
\hline Composition & T2-1 & T2-2 & T2-3 & T2-4 & T2-5 \\
\hline $\begin{array}{l}\text { Commercial } \\
\text { Grade } \mathrm{NaHCO}_{3}\end{array}$ & $16.8 \mathrm{~g}$ & $16.8 \mathrm{~g}$ & $16.8 \mathrm{~g}$ & $16.8 \mathrm{~g}$ & $16.8 \mathrm{~g}$ \\
\hline $\mathrm{NaCl}$ & $1.6 \mathrm{~g}$ & $1.6 \mathrm{~g}$ & $1.6 \mathrm{~g}$ & $1.6 \mathrm{~g}$ & $1.6 \mathrm{~g}$ \\
\hline $\begin{array}{ll}\text { Urea } & \text { (Nitrogen } \\
\text { source) } & \end{array}$ & $1.5 \mathrm{~g}$ & $2.0 \mathrm{~g}$ & $2.5 \mathrm{~g}$ & $3.0 \mathrm{~g}$ & $3.5 \mathrm{~g}$ \\
\hline TSP & $0.4 \mathrm{~g}$ & $0.4 \mathrm{~g}$ & $0.4 \mathrm{~g}$ & $0.4 \mathrm{~g}$ & $0.4 \mathrm{~g}$ \\
\hline $\begin{array}{ll}\text { MOP } & \text { (Muriate } \\
\text { potash) } & \end{array}$ & $0.98 \mathrm{~g}$ & $0.98 \mathrm{~g}$ & $0.98 \mathrm{~g}$ & $0.98 \mathrm{~g}$ & $0.98 \mathrm{~g}$ \\
\hline
\end{tabular}

TABLE III: COMPOSITION OF TREATMENT THREE MEDIUM

\begin{tabular}{|c|c|c|c|c|c|}
\hline \multicolumn{6}{|l|}{ T3 medium } \\
\hline Composition & T3-1 & T3-2 & T3-3 & T3-4 & T3-5 \\
\hline $\begin{array}{l}\text { Commercial } \\
\text { Grade } \mathrm{NaHCO}_{3}\end{array}$ & $8.0 \mathrm{~g}$ & $8.0 \mathrm{~g}$ & $8.0 \mathrm{~g}$ & $8.0 \mathrm{~g}$ & $8.0 \mathrm{~g}$ \\
\hline $\mathrm{NaCl}$ & $10.0 \mathrm{~g}$ & $10.0 \mathrm{~g}$ & $10.0 \mathrm{~g}$ & $10.0 \mathrm{~g}$ & $10.0 \mathrm{~g}$ \\
\hline $\begin{array}{ll}\mathrm{NaNO}_{3} & \text { (Nitrogen } \\
\text { source) } & \end{array}$ & $1.5 \mathrm{~g}$ & $2.0 \mathrm{~g}$ & $2.5 \mathrm{~g}$ & $3.0 \mathrm{~g}$ & $3.5 \mathrm{~g}$ \\
\hline $\mathrm{MgSO}_{4}$ & $0.15 \mathrm{~g}$ & $0.15 \mathrm{~g}$ & $0.15 \mathrm{~g}$ & $0.15 \mathrm{~g}$ & $0.15 \mathrm{~g}$ \\
\hline $\mathrm{CaCl}_{2}$ & $0.04 \mathrm{~g}$ & $0.04 \mathrm{~g}$ & $0.04 \mathrm{~g}$ & $0.04 \mathrm{~g}$ & $0.04 \mathrm{~g}$ \\
\hline TSP & $0.2 \mathrm{~g}$ & $0.2 \mathrm{~g}$ & $0.2 \mathrm{~g}$ & $0.2 \mathrm{~g}$ & $0.2 \mathrm{~g}$ \\
\hline MOP & $0.98 \mathrm{~g}$ & $0.98 \mathrm{~g}$ & $0.98 \mathrm{~g}$ & $0.98 \mathrm{~g}$ & $0.98 \mathrm{~g}$ \\
\hline
\end{tabular}


a) Mass culture of Spirulina platensis

Mass Culture was initiated in the culture unit. For one formulated medium 15 jars and altogether 45 jars to the three media with fixed aeration were used. Each treatment was added with $150 \mathrm{ml}$ of prepared medium to each concentration with $1 \mathrm{ml}$ of pure spirulina inoculation from same strata culture including the control. Within the culture unit, temperature was maintained at $35^{\circ} \mathrm{C}$ and the illumination was 4000 lux. During the culture period, $\mathrm{pH}$ of the culture was maintained once in three days. Media were added to every jars daily to maintain the $150 \mathrm{ml}$ of volume in each day to minimize the evaporation by heat.

\section{b) Measure growth rate}

Growth measurements were taken once in three days for a month with $1 \mathrm{ml}$ of the sample in the Sedgewick rafter cell, hand tally counter and Euromax TM light microscope.

To obtain Spirulina cell count, count was taken on diagonally 60 cells of Sedgewick rafter cell. Then average was calculated using following formula.

$$
\text { cell count }(1 \mathrm{ml})=\frac{\text { cell number }}{60} * 1000
$$

And the data were analyzed using the MINITAB 16.1 statistical software.

\section{RESULTS}

\section{A. $T 1$ medium}

There was a significant difference between growth and the different concentrations in $\mathrm{T} 1$ medium compared to control medium ( $p$ value $<0.05$ ). Concentration 1, 2 and 3 showed higher growth performance than control medium. Among them, concentration 3 showed the highest growth performance when considering T1 medium (FIG. I).

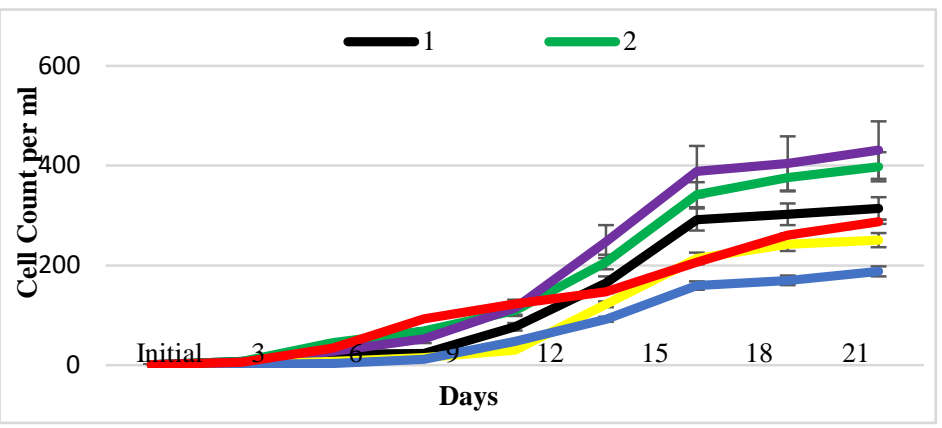

FIGURE 1: GROWTH PERFORMANCE OF S. platensis IN DIFFERENT CONCENTRATIONS OF T1 MEDIUM AGAINST CONTROL

\section{B. $T 2$ medium}

There was a significant difference between growth rate and different concentrations in $\mathrm{T} 2$ medium (FIG.II) compared to control medium. The control (Zarrouk's) medium showed higher growth performance than five concentrations in $\mathrm{T} 2$ medium.

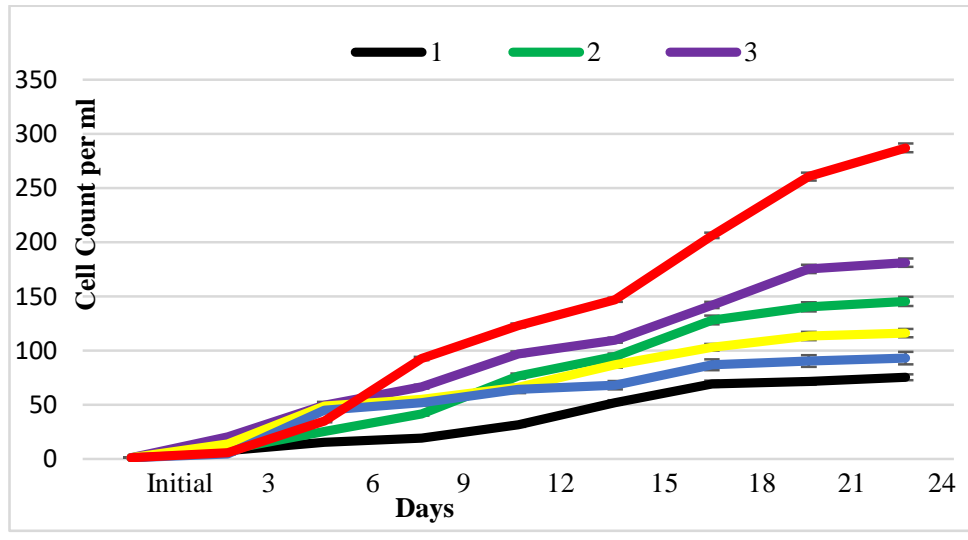

FIGURE II: GROWTH PERFORMANCE OF S. platensis IN DIFFERENT CONCENTRATIONS OF T2 MEDIUM AGAINST CONTROL

\section{T3 medium}

There was a significant difference between growth and the different concentrations in T3 medium (FIG.3) compared to control medium (p value $<0.05$ ). In T3 medium, Concentration 1,2 and 3 showed higher growth performance than control medium. Among them concentration 1 showed the highest growth performance. 


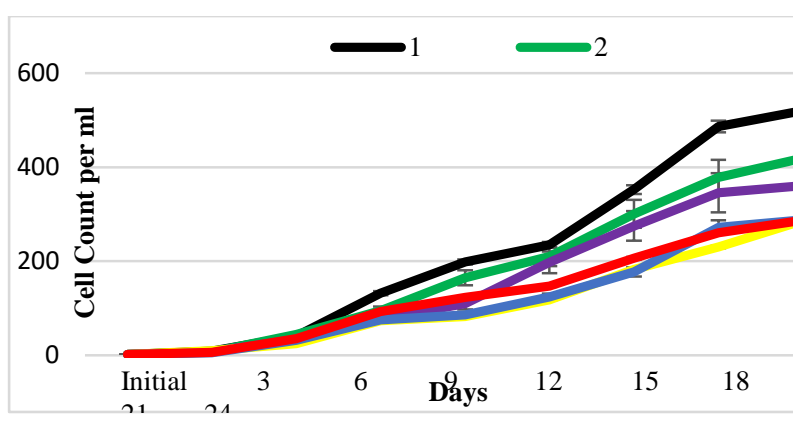

FIGURE III: GROWTH PERFORMANCE OF S. platensis IN DIFFERENT CONCENTRATIONS OF T3 MEDIUM AGAINST CONTROL

\section{Growth rate of T1, T2 and T3 medium}

There is a significant difference in growth rate between T1, T2, and T3 medium ( $\mathrm{p}<0.05)$. T1 medium initially showed slower growth rate having a highest growth rate during 15 th and 18th day (TABLE IV). T2 medium has been showed lowest growth rate performances throughout the study period. T3 medium has been showed higher growth rates in each day throughout the study period compared to the control medium and the T1 and T2 medium (FIG.IV).

TABLE IV: GROWTH RATE ANALYSIS OF S. platensis IN THREE GROWTH MEDIA AND CONTROL

\begin{tabular}{|r|l|l|l|l|}
\hline \multicolumn{1}{|c|}{ Days } & $\mathbf{T 1}$ & $\mathbf{T 2}$ & $\mathbf{T 3}$ & Control \\
\hline Initial & $1 \pm 0.00$ & $1 \pm 0.00$ & $1 \pm 0.00$ & $1 \pm 0.00$ \\
\hline 3 & $5.205 \pm 2.81$ & $10.959 \pm 5.86$ & $7.301 \pm 2.28$ & $5.836 \pm 0.88$ \\
\hline 6 & $21.07 \pm 16.12$ & $36.78 \pm 14.75$ & $34.58 \pm 7.88$ & $34.78 \pm 1.48$ \\
\hline 9 & $34.36 \pm 24.14$ & $46.85 \pm 16.74$ & $90.97 \pm 24.64$ & $92.78 \pm 2.57$ \\
\hline 12 & $75.78 \pm 36.63$ & $67.07 \pm 22.31$ & $128.09 \pm 49.68$ & $123.21 \pm 3.10$ \\
\hline 15 & $166.61 \pm 63.41$ & $82.24 \pm 21.37$ & $176.79 \pm 53.25$ & $146.99 \pm 3.48$ \\
\hline 18 & $279.13 \pm 95.30$ & $105.94 \pm 27.94$ & $257.67 \pm 76.59$ & $206.33 \pm 4.43$ \\
\hline 21 & $299 \pm 98.99$ & $118.21 \pm 38.55$ & $342.58 \pm 100.01$ & $260.73 \pm 6.47$ \\
\hline 24 & $316.39 \pm 104.11$ & $122.27 \pm 39.43$ & 105.95 & $\begin{array}{l}287.16 \pm \\
\end{array}$ \\
\hline
\end{tabular}

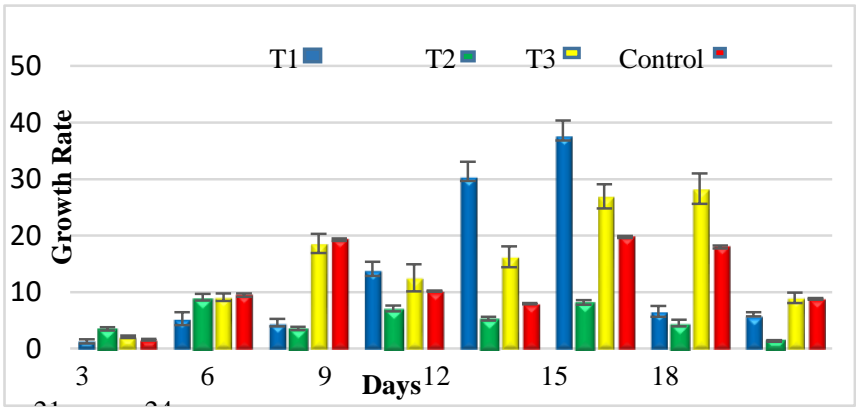

FIGURE IV: GROWTH RATE ANALYSIS OF S.platensis IN THREE GROWTH MEDIA AND CONTROL

\section{E. Growth Performance of S. platensis in three growth media against Control}

There were two media (T1 and T2) showed higher growth performance than the control medium and T3 medium shows the highest growth than other two media.

Graph shows the growth performance of three media and the best medium among three media against control medium (FIG.V). There is a significant difference between $\mathrm{T} 1, \mathrm{~T} 2$, and $\mathrm{T} 3$ medium when considering growth performance $(\mathrm{p}$ value<0.05). T3 medium showed the highest growth than other two media and control (TABLE V). 
TABLE V: GROWTH PERFORMANCE OF S.platensis IN T1, T2 AND T3 MEDIUM

\begin{tabular}{|r|l|l|l|l|}
\hline Days & T1 & T2 & T3 & Control \\
\hline $\mathbf{3}$ & $1.40 \pm 0.93$ & $3.32 \pm 1.95$ & $2.1 \pm 0.76$ & $1.61 \pm 0.29$ \\
\hline $\mathbf{6}$ & $5.28 \pm 4.58$ & $8.61 \pm 4.24$ & $9.10 \pm 2.67$ & $9.65 \pm 0.76$ \\
\hline $\mathbf{9}$ & $4.43 \pm 3.33$ & $3.36 \pm 2.02$ & $18.63 \pm 6.60$ & $19.34 \pm 0.48$ \\
\hline $\mathbf{1 2}$ & $13.81 \pm 6.00$ & $6.74 \pm 3.57$ & $12.54 \pm 9.35$ & $10.14 \pm 0.18$ \\
\hline $\mathbf{1 5}$ & $30.28 \pm 10.71$ & $5.06 \pm 2.25$ & $16.23 \pm 7.17$ & $7.93 \pm 0.13$ \\
\hline $\mathbf{1 8}$ & $37.51 \pm 11.01$ & $7.90 \pm 2.68$ & $26.96 \pm 8.21$ & $19.78 \pm 0.34$ \\
\hline $\mathbf{2 1}$ & $6.62 \pm 3.52$ & $4.09 \pm 3.89$ & $28.30 \pm 10.47$ & $18.13 \pm 0.68$ \\
\hline $\mathbf{2 4}$ & $5.80 \pm 2.49$ & $1.35 \pm 0.46$ & $9.00 \pm 3.66$ & $8.81 \pm 0.24$ \\
\hline
\end{tabular}

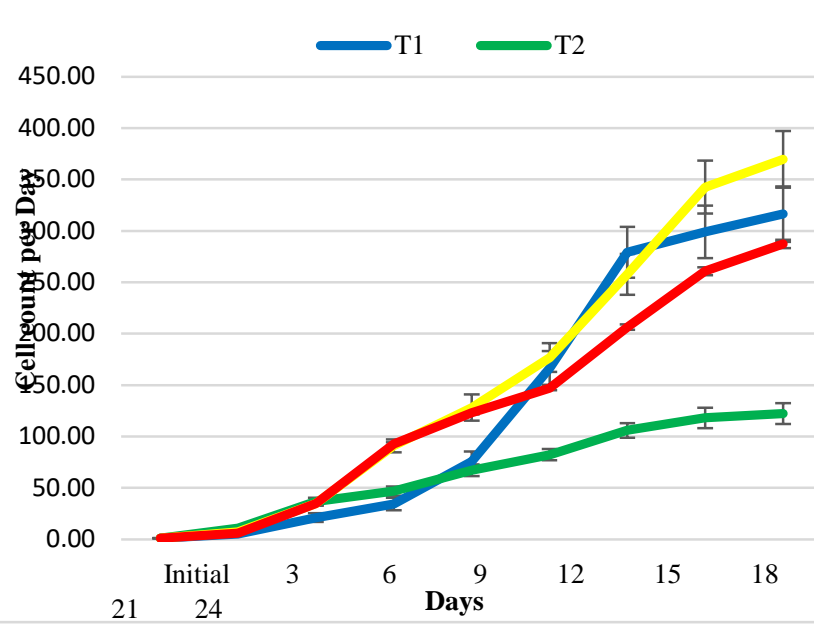

FIGURE V: GROWTH PERFORMANCE OF S.platensis IN THREE GROWTH MEDIA AGAINST CONTROL

\section{F. Cost analysis of formulated three media and control medium.}

Cost of the control medium is having around Rs. 150.00. Therefor all the formulated media are nearly three times cheaper than the Zarrouk's medium. (TABLE VI).

TABLE VI: COST ANALYSIS OF FORMULATED THREE MEDIA AND CONTROL MEDIUM

\begin{tabular}{|l|l|l|l|}
\hline $\begin{array}{l}\text { Zarrouk } \\
\text { medium (1L) }\end{array}$ & $\begin{array}{l}\text { T1 Medium } \\
\text { (1L) }\end{array}$ & $\begin{array}{l}\text { T2 Medium } \\
\text { (1L) }\end{array}$ & $\begin{array}{l}\text { T3 Medium } \\
(\mathbf{1 L})\end{array}$ \\
\hline Rs 156.88 & Rs 45.23 & Rs 44.42 & Rs 49.76 \\
\hline
\end{tabular}

\section{DISCUSSION}

The present investigation was focused on the formulation of a cheaper medium for the growth of Spirulina platensis, by substitution of essential nutrients of Zarrouk's medium using locally available agricultural fertilizers, such as Urea, Albert solution, SSP and MOP.

Mass production of Spirulina sp. is a complex process including a large number of chemicals and the environment needs to be acclimatized to meet the essential requirements for their effective growth. There are several limitations to the growth of cyanobacteria; physical, physiological and economic limitations are of major importance (Mostert and Grobbelaar, 1987). In developing countries such as Sri Lanka, emphasis is placed more on the production costs.

Three media were formulated as $\mathrm{T} 1, \mathrm{~T} 2$, and $\mathrm{T} 3$. The study aimed that evaluate the effect of different nitrogen sources for the growth of Spirulina Platensis. The addition and deletion of other major constituents of Zarrouk medium was investigated. In the formulated media; SSP, MOP, Albert solution and commercial grade $\mathrm{NaHCO}_{3}$ replaced with $\mathrm{KH}_{2} \mathrm{PO}_{4}$, EDTA, A5 micronutrient solution, $\mathrm{K}_{2} \mathrm{SO}_{4}, \mathrm{FeSO}_{4}$, and laboratory grade $\mathrm{NaHCO}_{3}$. On the basis of these studies, cell count was found to be a reliable indicator of cell growth.

In T1 medium, Spirulina grown in $\mathrm{ZM}$ medium substituted with Urea in place of $\mathrm{NaNO}_{3}$, and Albert solution was added instead of EDTA and A5 micronutrient solution. Concentration 1, 2, and 3 showed significantly higher growth performance $(\mathrm{p}<0.05)$ in $\mathrm{T} 1$ than control medium. Urea amount in concentration 1,2 , and 3 were $2.0 \mathrm{~g}, 2.5 \mathrm{~g}$, and $3.0 \mathrm{~g}$ respectively. Concentration 3 showed the highest growth performance in $\mathrm{T} 1$ medium. $\mathrm{NaCl}$ of $2.0 \mathrm{~g}$ was added to the formulated media to maintain 15 ppt salinity level when preparing the one litter of $\mathrm{ZM}$ medium.

Phosphorus is a major nutrient required for the growth and primary productivity of algae. Mostert and Grobbelaar, (1987) have showed the vital role of phosphorus in maintaining high production rates of microalgae mass cultures. Hence for T2 medium, $\mathrm{KH}_{2} \mathrm{PO}_{4}$, EDTA and A5 micronutrients were replaced with TSP. Spirulina could effectively utilize 'Phosphorus' in the form of $\mathrm{P}_{2} \mathrm{O}_{5}$ supplied by TSP and MOP was used in T2 medium instead of $\mathrm{K}_{2} \mathrm{SO}_{4}$ in the $\mathrm{ZM}$ medium. In here Urea was also 
used as a nitrogen source. But T2 medium did not show better growth performance compared to the control medium even the each concentrations showed the significantly different $(\mathrm{p}<0.05)$ growth. Reason would be the lack of minor nutrients in the used chemicals and fertilizers. $\mathrm{NaCl}$ of $1.6 \mathrm{~g}$ was added to the formulated media to maintain $15 \mathrm{ppt}$ salinity level.

In $\mathrm{T} 3$ medium $\mathrm{NaNO}_{3}$ used as a nitrogen source same as the ZM medium. In order to further reduce the cost, Spirulina sp. was grown in T3 with varied concentrations of sodium nitrate $1.5 \mathrm{~g}, 2.0 \mathrm{~g}, 2.5 \mathrm{~g}$, $3.0 \mathrm{~g}$ and $3.5 \mathrm{~g}$ (per 1L) and compared with $\mathrm{ZM}$ containing $2.5 \mathrm{~g} \mathrm{lL} \mathrm{NaNO}_{3}$. The study revealed that all the concentrations of T3 medium showed significantly higher growth performance $(\mathrm{P}<0.05)$ compared to the control medium. Among the three concentrations, concentration 1 showed the highest growth performances. Therefore, $1.5 \mathrm{~g}$ of $\mathrm{NaNO}_{3}$ was the effective amount for optimum growth of Spirulina platensis in T3 medium according to this study. But Raoof et al., (2006) mentioned that further reduction of $\mathrm{NaNO}_{3}$ concentration to 1.5 or $1 \mathrm{~g} / \mathrm{L}$ lead to a significant decrease of growth performances.

Sulphur is an essential component of certain essential amino acids and vitamins and also necessary for growth of Spirulina. So the sulfur requirement was met in $\mathrm{T} 3$ medium by adding $\mathrm{MgSO}_{4}$. Potassium requirement for Spirulina was entirely met by MOP in T3 medium. Spirulina is having a high bicarbonate requirement, which acts not only as a carbon source but also helps to maintain alkaline conditions, which are favorable for the growth of Spirulina.

Further modification involved the replacement of analytical grade $\mathrm{NaHCO}_{3}$ over commercial grade $\mathrm{NaHCO}_{3}$ (Backing powder) in all newly formulated media, due to analytical grade $\mathrm{NaHCO}_{3}$ is highly expensive in Sri Lankan context. $\mathrm{NaHCO}_{3}$ (Backing powder) $8.00 \mathrm{~g}$ used in $\mathrm{T} 3$ medium comparing the actual growth requirements of Spirulina. This is revealing of the fact that the amount of calcium chloride cannot be reduced further in the formulated $\mathrm{T} 3$ medium because Calcium is fundamentally required for cell membrane activity (Raoof et al., 2006). In T3 medium TSP and MOP fertilizers were added for the previous reasons above mentioned in the $\mathrm{T} 2$ medium.

\section{CONCLUSION}

The newly formulated T3 medium gives the better growth performance compared with Zarrouk's medium, fulfilling the basic requirement of providing a simple and inexpensive culture medium. All formulated media are nearly three times cheaper than the control medium. Therefore, the merits of the formulated media are clearly highlighted, not only as the low-cost alternative but also as a highly productive input can be used profitably by the rural population in developing countries like Sri Lanka, for large-scale biomass production of protein-rich Spirulina sp.

\section{REFERENCES}

[1] Belay, A., Ota, Y., Miyakawa, K. and Shimamatsu, H., 1993. Current knowledge on potential health benefits of Spirulina. Journal of applied Phycology, 5(2), pp.235241.

[2] Das P., Aziz S.S., Obbard J.P., 2011. Two phase microalgae growth in the open system for enhanced lipid productivity. Renew Energy. 36(9), pp.2524-8.

[3] Devi, M.A. and Venkataraman, L.V., 1984. Functional properties of protein products of mass cultivated blue-green alga Spirulina platensia. Journal of Food Science, 49(1), pp.24-27.

[4]Gohl B., 1991. Tropical Feeds.Version1.7 FAO/Oxford Computer Journals Ltd, Oxford, UK

[5] Khan, M.I., Shin, J.H. and Kim, J.D., 2018.The promising future of microalgae: current status, challenges, and optimization of a sustainable and renewable industry for biofuels, feed, and other products. Microb Cell Fact 17, 36.

[6] Liu, Q., Hung, Y., Zhang, R., Cai, T \& Cai, Y., 2016. Medical application of Spirulina platensis derived Cphycocyanin. Evidence-Based Complementary Alternative Medicine, 2016.FAO, A Review on culture, production and use of spirulina as food for humans and feed for domestic animals and fish food. Food and Agricultural organization of the United Nations.

[7] Michael A.B., 2013. High-value products from microalgae their development and commercialization. $J$ Appl Phycol. 25. Pp 743-56.

[8] Mostert E.S., Grobbelaar J.U., 1997. The influence of nitrogen and phosphorus on algal growth and quality in outdoor mass algal cultures. Biomass. 13. pp 219-33.

[9] Raoof, B., Kaushik, B. and Prasanna, R., 2006. Formulation of a low-cost medium for mass production of Spirulina. Biomass and bioenergy, 30. pp 537-542.

[10] Vonshak, A., 1988. Spirulina platensis (Arthrospira): physiology. cell biology and biotechnology. Biomass. 15. pp 233-47. 